\title{
Dominance of sulfur-fueled iron oxide reduction in low-sulfate freshwater sediments
}

\author{
Colleen M Hansel ${ }^{1}$, Chris J Lentini ${ }^{2}$, Yuanzhi Tang ${ }^{3}$, David T Johnston ${ }^{4}$, Scott D Wankel ${ }^{1}$ \\ and Philip M Jardine \\ ${ }^{1}$ Department of Marine Chemistry and Geochemistry, Woods Hole Oceanographic Institution, Woods Hole, \\ MA, USA; ${ }^{2}$ School of Engineering and Applied Sciences, Harvard University, Cambridge, MA, USA; ${ }^{3}$ School of \\ Earth and Atmospheric Sciences, Georgia Institute of Technology, Atlanta, GA, USA and ${ }^{4}$ Department of \\ Earth and Planetary Sciences, Harvard University, Cambridge, MA, USA
}

\begin{abstract}
A central tenant in microbial biogeochemistry is that microbial metabolisms follow a predictable sequence of terminal electron acceptors based on the energetic yield for the reaction. It is thereby oftentimes assumed that microbial respiration of ferric iron outcompetes sulfate in all but high-sulfate systems, and thus sulfide has little influence on freshwater or terrestrial iron cycling. Observations of sulfate reduction in low-sulfate environments have been attributed to the presumed presence of highly crystalline iron oxides allowing sulfate reduction to be more energetically favored. Here we identified the iron-reducing processes under low-sulfate conditions within columns containing freshwater sediments amended with structurally diverse iron oxides and fermentation products that fuel anaerobic respiration. We show that despite low sulfate concentrations and regardless of iron oxide substrate (ferrihydrite, Al-ferrihydrite, goethite, hematite), sulfidization was a dominant pathway in iron reduction. This process was mediated by (re)cycling of sulfur upon reaction of sulfide and iron oxides to support continued sulfur-based respiration-a cryptic sulfur cycle involving generation and consumption of sulfur intermediates. Although canonical iron respiration was not observed in the sediments amended with the more crystalline iron oxides, iron respiration did become dominant in the presence of ferrihydrite once sulfate was consumed. Thus, despite more favorable energetics, ferrihydrite reduction did not precede sulfate reduction and instead an inverse redox zonation was observed. These findings indicate that sulfur (re)cycling is a dominant force in iron cycling even in low-sulfate systems and in a manner difficult to predict using the classical thermodynamic ladder. The ISME Journal (2015) 9, 2400-2412; doi:10.1038/ismej.2015.50; published online 14 April 2015
\end{abstract}

\section{Introduction}

A central tenet in the Earth science is that organic carbon remineralization is coupled to a predictable sequence of oxidant consumption. This sequence, commonly referred to as the thermodynamic ladder or redox tower, is based on the overall energetic gain of the oxidation of organic carbon (or $\mathrm{H}_{2}$ ) coupled to the reduction of terminal electron acceptors including oxygen, nitrate, manganese, ferric iron and sulfate. This predictable energy-based hierarchy thus defines our understanding of how microbial metabolisms are organized both spatially and temporally in wide ranging environments, from groundwaters and terrestrial soils to marine sediments. Extending beyond the modern, this biogeochemical framework

Correspondence: CM Hansel, Department of Marine Chemistry and Geochemistry, Woods Hole Oceanographic Institution, 266 Woods Hole Road, MS\#52, Woods Hole, MA 02543, USA.

E-mail: chansel@whoi.edu

*Deceased

Received 18 August 2014; revised 24 February 2015; accepted 2 March 2015; published online 14 April 2015 underpins all reconstructions of paleoenvironments, which in turn inform our understanding of the evolution of the Earth's surface and in parallel, the biosphere. Under the umbrella of this classic redox tower (Champ et al., 1979), microbial reduction of ferric iron $\left(\mathrm{Fe}^{3+}\right)$ is expected to outcompete sulfate with the exception of high-sulfate systems (that is, marine environments; Froelich et al., 1979; Patrick and Henderson, 1981; Lovley and Phillips 1987; Hoehler et al., 1998). Thus, it is widely accepted that sulfate reduction has little, if any, influence on the freshwater and terrestrial iron cycle.

Iron oxides, the dominant ferric iron species in natural systems, however, exist in a spectrum of structures that span over $100 \mathrm{mV}$ in reduction potential, with more crystalline phases closely coinciding with sulfate potentials. In fact, Gibbs energy $\left(\Delta G_{\mathrm{r}}\right)$ calculations predict that the reduction of sulfate is less favorable than highly reactive Fe hydroxides (that is, ferrihydrite; nominally $\left.\mathrm{Fe}(\mathrm{OH})_{3}\right)$, but more energetically favorable than reduction of more crystalline $\mathrm{Fe}$ (hydr)oxides (for example, goethite $(\alpha-\mathrm{FeOOH})$ and hematite $\left(\alpha-\mathrm{Fe}_{2} \mathrm{O}_{3}\right)$; 
Postma and Jakobsen, 1996). Further, new modeling approaches taking into account the requirements of energy capture within metabolic energy budgets indicated that total energy and metabolically usable energy are not necessarily interchangeable (Bethke et al., 2011; LaRowe and Van Cappellen, 2011). These modeling predictions were confirmed in a number of environmental and laboratory settings, where the reduction of crystalline phases such as goethite and hematite either preceded or coincided with sulfate reduction (Postma and Jakobsen, 1996; Jakobsen and Postma, 1999; Bethke et al., 2011; Williams et al., 2011). Although these results pointed out the need to incorporate mineralogical structure and energy budget constraints in application of this paradigm, they still broadly keep with thermodynamic predictions as a robust metabolic predictor. As such, in soils and sediments dominated by more poorly crystalline iron oxides (for example, ferrihydrite), where energetics clearly favor iron reduction, sulfate reduction is presumed to be a minor contributor to iron reduction and carbon mineralization pathways.

Consequently, frequent observations of active sulfate reduction and cycling within a range of low-sulfate natural environments have been attributed, in part, to the presumed presence of highly crystalline iron oxides. Sulfur recycling in natural systems involves a number of oxidation, reduction and disproportionation reactions involving various reactive intermediates that may be hidden within a cryptic sulfur cycle (Jorgensen, 1990; Elsgard and Jorgensen, 1992; Canfield et al., 2010). Ferric iron hosted in crystalline minerals has been implicated in this cycling and the resupply of sulfate and/or intermediate sulfur species to fuel this cryptic cycle (Holmkvist et al., 2011; Pester et al., 2012). It has been postulated that active and sustained sulfate reduction was allowed despite low sulfate concentrations due to regeneration of sulfate initiated by reaction of the sulfide with this metabolically unavailable yet chemically reactive iron pool. Based on the widely held assumption that ferrihydrite will be consumed before sulfate, it is therefore presumed that active sulfate reduction only occurs in either the absence of iron oxides or in the presence of highly crystalline Fe phases.

Here we conducted a systematic investigation of the role of iron oxides on sulfate reduction by indigenous microbial populations within natural freshwater sediments. In detail, we conducted a series of flow-through column experiments containing either two-line ferrihydrite-, Al-substituted ferrihydrite-, goethite- or hematite-coated quartz sand mixed with natural freshwater sediments. The influent solution consisted of calcite-buffered $(\mathrm{pH}$ 7.2) artificial freshwater supplemented with low levels of sulfate $(200 \mu \mathrm{M})$ and dissolved organic carbon in the form of both lactate and acetate $(\sim 500 \mu \mathrm{M}$ each). These substrates represent two dominant fermentation products that fuel anaerobic respiration, including both iron- and sulfatereducing populations (Lovley et al., 2004). We show that sulfate was a driving force in iron reduction regardless of the iron oxide structure, including the highly reactive and most bioavailable phase ferrihydrite, and in the presence of low sulfate levels consistent with freshwater and terrestrial environments.

\section{Materials and methods}

\section{Mineral synthesis}

Two-line ferrihydrite, Al-substituted ferrihydrite, goethite and hematite were prepared following the procedure in Schwertmann and Cornell (2000). Goethite and hematite were washed with hydroxylamine to remove disordered regions. All minerals were washed several times either via dialysis or mixing and centrifugation with deionized water. Washed minerals slurries were mixed with pure quartz sand and dried at $20^{\circ} \mathrm{C}$ under convection while being periodically stirred. The dried Fe oxidecoated sands containing $10 \mathrm{mg}$ iron per gram sand were suspended in water and washed to remove any loose mineral not attached to the sand. Both X-ray diffraction (Harvard University) and X-ray absorption spectroscopy (Stanford Synchrotron Radiation Lightsource) were used to verify the composition and purity of the Fe hydroxide phases. No changes in mineralogy were noted after sterilization.

\section{Sediment collection and preparation}

Sediment was collected from Ashumet Pond, Falmouth, MA, USA, in Spring of 2012. Three shallow sediment cores were collected within the pond downgradient of the barrier with a water depth of $\sim 0.5 \mathrm{~m}$. Upon sampling, the cores were stored on ice, transferred back to the laboratory and placed in an anaerobic chamber $\left(97 \% \mathrm{~N}_{2}: 3 \% \mathrm{H}_{2}\right)$. The outer $1 \mathrm{~cm}$ of the cores was discarded, the remaining sediment was combined and mixed, and $10 \mathrm{~g}$ of the homogenized sediment was placed in anaerobic serum bottles containing sterile HEPES buffer (10 mM). The sediments were incubated for 21 days in pond water to draw down the concentration of labile electron donors and acceptors indigenous to the sediment. Before inoculation, the sediment was sterilely sieved $\left(1 \mathrm{~mm}^{2}\right)$ within the anaerobic chamber to ensure uniform distribution and remove larger pebbles. The sediment was mixed (1:10) thoroughly with iron oxide-coated or pure quartz sand (no Fe control). The inoculated iron oxide-coated sand was allowed to equilibrate for $2 \mathrm{~h}$ before transfer to the columns.

\section{Column experiments}

Ten columns $\left(1.5 \times 10 \mathrm{~cm}^{2}\right.$; Hansel et al., 2004) were packed under continuous vibration with approximately $40 \mathrm{~g}$ of Fe oxide-coated sand resulting in a concentration of $\mathrm{Fe}$ within the columns of 
approximately $2400 \mu \mathrm{mol}$. The columns were secured vertically in an anaerobic glovebox and artificial groundwater media was pumped through the bottom and out the top of the column at a velocity of $0.2 \mathrm{~m}$ per day (within normal groundwater flow rates) using a shared peristaltic pump. The artificial groundwater medium contained the following ingredients (in $\mu \mathrm{M}$ ): $67 \mathrm{KCl} ; 82 \mathrm{NaCl} ; 200 \mathrm{MgSO}_{4} ; 215 \mathrm{MgCl}_{2} \bullet 6 \mathrm{H}_{2} \mathrm{O}$; $20 \mathrm{KH}_{2} \mathrm{PO}_{4} ; 320 \mathrm{NH}_{4} \mathrm{Cl}$ and $100 \mathrm{\mu l} \mathrm{l}^{-1}$ each of Fe-free Wolfe's trace element and vitamin stock solutions. Both lactate and acetate were provided as electron donors to provide a final concentration of $500 \mu \mathrm{M}$ each. The medium was equilibrated with calcite $\left(\sim 0.4 \mathrm{~g} \mathrm{l}^{-1}\right)$ and $\mathrm{pCO}_{2}$ at $0.02 \mathrm{~atm}$ (pH $\sim 7$; Benner et al., 2002; Hansel et al., 2003).

The ten columns were run in parallel with half terminated after 19 days and the other half following 29 days of reaction. Effluent solution chemistry was monitored daily while solid-phase and microbiological analysis was conducted upon termination at each time point.

\section{Batch incubations}

Batch incubations were conducted with Desulfovibrio putealis and Desulfovibrio vulgaris, bacteria that couple sulfate and sulfur reduction to the incomplete oxidation of lactate to acetate. Isolated strains of $D$. putealis and $D$. vulgaris were obtained in a parallel study via serial batch enrichment cultures conducted under similar geochemical conditions (Lentini et al., 2012; Lentini, 2013). Cultures enriched in the presence of goethite and lactate were transferred successively every couple months for 2 years into fresh liquid media. Pure isolates were obtained by plating the cultures onto lactate- and sulfate-amended groundwater solidified media. The isolated strains shared 95\% and 99\% $16 \mathrm{~S}$ rRNA sequence identity with $D$. vulgaris and $D$. putealis, respectively (see Lentini et al., 2012; Lentini 2013). Standard practices for sterile and anaerobic media preparation and cultivation were used throughout the experiment. In addition, all gases were passed through heated copper fillings to remove any trace oxygen. Cell preparation and incubations were conducted in an anaerobic bicarbonate-buffered $(\mathrm{pH}=7.2)$ basal media prepared by boiling and cooling under ultra-high purity $\mathrm{N}_{2} / \mathrm{CO}_{2}$ (80:20) gas. The basal media contained: $4.41 \mathrm{mM} \quad \mathrm{KH}_{2} \mathrm{PO}_{4}$, $5.62 \mathrm{mM} \quad \mathrm{NH}_{4} \mathrm{Cl}, \quad 4.2 \mathrm{mM} \quad \mathrm{MgCl}_{2}, \quad 0.9 \mathrm{~mm} \quad \mathrm{CaCl}_{2}$, $29.7 \mathrm{~mm} \mathrm{NaHCO}_{3}$ and an Fe-free trace metal stock.

Cells were initiated from glycerol stocks within the basal medium, amended with $30 \mathrm{~mm}$ lactate, $15 \mathrm{~mm}$ sulfate and Fe added to the trace metal stock. Seed cultures were grown in the dark at room temperature to late exponential phase. Exponentially grown cells were centrifuged $(6000 \mathrm{~g})$ at $10^{\circ} \mathrm{C}$ for $10 \mathrm{~min}$ under anaerobic conditions (under $80 \% \mathrm{~N}_{2}: 20 \% \mathrm{CO}_{2}$ ). The supernatant was discarded and the cell pellet washed and resuspended in the basal media above without lactate and sulfate.
The prepped seed culture was inoculated into fresh basal media containing sulfate (as $\mathrm{MgSO}_{4}$; 0-800 $\mu \mathrm{M})$, ferrihydrite $(3.2 \mathrm{~mm})$ and sodium lactate $\left(3.2 \mathrm{~mm}\right.$ ) to obtain a cell density of $5 \times 10^{6}$ cells per $\mathrm{ml}$ ( $5 \%$ inoculum). Incubations were conducted for up to $250 \mathrm{~h}$ in the dark within anaerobic serum vials stored in the glovebox.

\section{Measurement of dissolved and gaseous species}

Within the column experiments, effluent chemistry was monitored daily by collecting the solution coming out of the column (effluent) into a sealed serum vial. In order to avoid the build up of backpressure, the serum vials were exhausted into a secondary vial, which contained a $\mathrm{ZnCl}_{2}$ solution to trap gaseous sulfide. Approximately every $24 \mathrm{~h}$, the effluent solution was weighed, filtered $(0.2 \mu \mathrm{m})$ and measured for the following: ferrous $\mathrm{Fe}$, total $\mathrm{Fe}$, dissolved sulfide, alkalinity, $\mathrm{pH}$, organic acids and major cations and anions (including sulfate and thiosulfate).

Within the batch incubations, aqueous samples were collected in an anaerobic glovebox using degassed anaerobic syringes. To maintain a constant headspace, the sample volume was replaced with an equal volume of $\mathrm{N}_{2}: \mathrm{CO}_{2}$ gas. Soluble $\mathrm{Fe}(\mathrm{II})$ and sulfide were measured immediately. Zinc chloride ( $0.1 \mathrm{~mm}$ final concentration) was added to aqueous samples stored for cations and anions to remove any residual sulfide from solution. Samples were stored at $-20^{\circ} \mathrm{C}$ until analysis.

$\mathrm{Fe}(\mathrm{II})$ and total $\mathrm{Fe}\left(\mathrm{Fe}_{\mathrm{TOT}}\right)$ were measured using a modified Ferrozine method with total Fe measured by first reducing $\mathrm{Fe}(\mathrm{III})$ to $\mathrm{Fe}(\mathrm{II})$ via reaction with hydroxylamine under a flame (Stookey, 1970). Aqueous sulfide was measured by the Cline assay using 1,4-benzenediamine, $N, N$-dimethyl sulfate, sulfuric acid and ferric chloride hexahydrate (Cline, 1969). Major cations were measured via inductively coupled plasma optical emission spectroscopy. For both of these colorimetric assays, samples were incubated in the anaerobic chamber in the dark for 20 min before measurement on a Varian ultraviolet-visible spectrophotometer. Organic acids and major anions (for example, sulfate, thiosulfate) were measured using ion chromatography.

\section{Measurement of solid-phase species}

Within the anaerobic chamber, solid samples were carefully extracted using a syringe from the serum vials (batch incubations) or by scooping out the sediment from the glass columns. The column sediments were divided in half according to weight to allow for analyses and comparison of the top and the bottom of the reacted sediments.

Solid-phase $\mathrm{Fe}(\mathrm{II})$ and total $\mathrm{Fe}$ were measured by digesting a weighed amount of solid in anaerobic $6 \mathrm{M}$ $\mathrm{HCl}$ within the anaerobic chamber for several hours. $\mathrm{Fe}^{2+}$ and total $\mathrm{Fe}$ were then measured using the Ferrozine method (as described above) with an 
ammonium acetate buffer where needed. For the column sediments, acid volatile sulfide was measured by addition of the solid-phase to anaerobic $\mathrm{HCl}$ under an $\mathrm{N}_{2}$ flow. The gas was passed though a $\mathrm{Zn}$ hydroxide EDTA solution for approximately $4 \mathrm{~h}$ and measured via the Cline method (Cline, 1969). For the batch incubations, slurry (solid and solution) samples were collected via syringe and added directly to the Cline reagents. Samples were incubated in the dark for $15 \mathrm{~min}$ before centrifugation $(15 \mathrm{~min}$ at 11 $000 \mathrm{~g}$ ). The supernatant was analyzed on the spectrophotometer $(670 \mathrm{~nm})$. Solid-phase sulfide was determined as the total Cline extractable sulfide minus the filterable sulfide. Measurements of solid-phase associated sulfide within the batch experiments by direct Cline extraction was equivalent to values obtained via acid volatile sulfide.

Secondary minerals were characterized via X-ray absorption spectroscopy on solid samples that were stored anaerobically and frozen until analysis at the Stanford Synchrotron Radiation Lightsource. For Fe analysis, the samples were dried in an anaerobic chamber and mounted onto Teflon holders with Kapton tape. For S, dried samples were mounted onto S-free Lexan. Fe and S X-ray absorption spectra were collected within a He-purged sample chamber under a continuous He flow with a Lytle detector at beamline 4-3. The spectra were calibrated with $\mathrm{Fe}(0)$ and thiosulfate for $\mathrm{Fe}$ and $\mathrm{S}$, respectively. To minimize any exposure to oxygen and avoid sample oxidation, all samples were prepared and stored in the laboratory glovebox at the synchrotron. Samples were transferred from the glovebox to the beamline using portable anaerobic boxes and placed directly into a He-purged anaerobic bag surrounding the sample holder chamber within the beamline hutch.

Identification and quantification of the secondary $\mathrm{Fe}$ and $\mathrm{S}$ phases were determined by fitting either the $k^{3}$-weighted EXAFS (Fe) or XANES region (S) of the unknown spectra (samples) with a linear combination of reference compounds using the program SIXPack (Webb, 2005) and as described in detail previously (Hansel et al., 2003). Linear combinations of the empirical model spectra were optimized where the only adjustable parameters were the fractions of each model compound contributing to the fit. The goodness of fit was established by minimization of the $R$-factor (Newville, 2001).

\section{Microbial community characterization}

DNA was extracted from the solid-phase samples and sequenced by Molecular Research LP. DNA was extracted using the MOBIO PowerSoil (MO BIO, Carlsbad, CA, USA) as per the manufacturer instructions. Bacterial tag-encoded pyrosequencing (bTEFAP) was conducted by the Research and Testing Laboratory (Lubbock, TX, USA) as described previously (Dowd et al., 2008). Primers 28 F (Ludwig et al., 1993) and $519 \mathrm{R}$ (Ruffroberts et al., 1994) were used to sequence variable regions V1-V3 of the $16 \mathrm{~S}$
rRNA gene. A single-step 30 cycle PCR using HotStarTaq Plus Master Mix Kit (Qiagen, Valencia, CA, USA) was used under the following conditions: $94^{\circ} \mathrm{C}$ for $3 \mathrm{~min}$, followed by 28 cycles of $94^{\circ} \mathrm{C}$ for $30 \mathrm{~s} ; 53^{\circ} \mathrm{C}$ for $40 \mathrm{~s}$ and $72^{\circ} \mathrm{C}$ for $1 \mathrm{~min}$; after which a final elongation step at $72{ }^{\circ} \mathrm{C}$ for $5 \mathrm{~min}$ was performed. Following PCR, all amplicon products from different samples were mixed in equal concentrations and purified using Agencourt Ampure beads (Agencourt Bioscience, Beverly, MA, USA). Samples were sequenced utilizing Roche 454 FLX titanium instruments and reagents and following the manufacturer's guidelines.

Raw sequencing reads were quality trimmed in QIIME (Caporaso et al., 2010), and chimeric sequences were removed from the trimmed singleton reads by checking against a chimera-free database of $16 \mathrm{~S}$ rRNA gene sequences (GreenGenes; DeSantis et al., 2006) using UCHIME (Edgar et al., 2011). Sequences were removed from the data set that were short read $(<200 \mathrm{bp})$, had ambiguous base calls or were homopolymer runs exceeding $6 \mathrm{bp}$. Libraries from different samples were size normalized by reducing all libraries to the size of the smallest sample. This resulted in 609 high-quality sequences per library after normalization. Operational taxonomic units were defined by clustering at $3 \%$ divergence and classified using the RDP Naïve Bayesian Classifier and a bootstrap cutoff of $80 \%$ (Wang et al., 2007).

\section{Results and discussion}

Consistent with thermodynamic predictions (Table 1) and previous results from natural and engineered systems (Postma and Jakobsen, 1996; Jakobsen and Postma, 1999; Bethke et al., 2011), the reduction of both goethite and hematite was dominated by reaction with biologically generated sulfide despite low sulfate $(<200 \mu \mathrm{M})$ concentrations. Within sediment columns amended with goethite and hematite, lactate was completely consumed and sulfate fully reduced to sulfide soon after carbon addition (Figures 1 and 2). Here, only minor levels of sulfide $(1-5 \%$ of total sulfide measured) were eluted from the column (Figures 1 and 2) and instead sulfide was scavenged near the bottom of the columns as solid-phase FeS (Supplementary Table 1 and Supplementary Figure 1). A corresponding dominance of known lactateoxidizing, sulfate-reducing (Desulfovibrio and Desulfosporomusa) genera (Rabus et al., 2006) were observed throughout the columns, accounting for more than $80 \%$ and $68 \%$ of the $16 \mathrm{~S}$ rRNA sequences in the goethite and hematite columns, respectively (Figure 3 and Supplementary Table 2). In contrast, known iron-reducing bacterial genera (for example, Geobacter spp., Shewanella spp.; Lovley et al., 2004; Weber et al., 2006) were not detected within the columns. Solid-associated ferrous iron decreased downgradient in parallel with declining FeS levels 
Table 1 Reactions of particular relevance in this study. The Gibbs energy using the influent and effluent aqueous conditions ${ }^{\mathrm{a}, \mathrm{b}}$ are calculated using two $\Delta \mathrm{G}_{\mathrm{f}}$ for two-line ferrihydrite with varying structural water content ${ }^{\mathrm{c}}$ (results for less hydrated form given in parentheses). Based on Bethke and others (2011), the amount of usable energy are also calculated ${ }^{\mathrm{d}}$ for Fe(III) and sulfate reduction

\begin{tabular}{|c|c|c|c|}
\hline & Influent ${ }^{a, c} \Delta \mathrm{G}_{r}$ per mol $C$ & Effluent ${ }^{b, c} \Delta \mathrm{G}_{r}$ per mol $C$ & $\Delta \mathrm{G}_{u}{ }^{d}$ \\
\hline \multicolumn{4}{|l|}{ Metabolic reactions: } \\
\hline (1) $\mathrm{C}_{3} \mathrm{H}_{5} \mathrm{O}_{3}^{-}+4 \mathrm{Fe}(\mathrm{OH})_{3}+7 \mathrm{H}^{+}=\mathrm{C}_{2} \mathrm{H}_{3} \mathrm{O}_{2}^{-}+\mathrm{HCO}_{3}^{-}+4 \mathrm{Fe}^{2+}+10 \mathrm{H}_{2} \mathrm{O}$ & $-313(-1241)$ & $-35(-963)$ & 257 \\
\hline (2) $\mathrm{C}_{2} \mathrm{H}_{3} \mathrm{O}_{2}^{-}+8 \mathrm{Fe}(\mathrm{OH})_{3}+15 \mathrm{H}^{+}=2 \mathrm{HCO}_{3}^{-}+8 \mathrm{Fe}^{2+}+20 \mathrm{H}_{2} \mathrm{O}$ & $-481(-2337)$ & $-35(-1891)$ & 425 \\
\hline (3) $\mathrm{C}_{3} \mathrm{H}_{5} \mathrm{O}_{3}^{-}+4 \mathrm{FeOOH}+7 \mathrm{H}^{+}=\mathrm{C}_{2} \mathrm{H}_{3} \mathrm{O}_{2}^{-}+\mathrm{HCO}_{3}^{-}+4 \mathrm{Fe}^{2+}+6 \mathrm{H}_{2} \mathrm{O}$ & -230 & 48 & 174 \\
\hline (4) $\mathrm{C}_{2} \mathrm{H}_{3} \mathrm{O}_{2}^{-}+8 \mathrm{FeOOH}+15 \mathrm{H}^{+}=2 \mathrm{HCO}_{3}^{-}+8 \mathrm{Fe}^{2+}+12 \mathrm{H}_{2} \mathrm{O}$ & -315 & 131 & 258 \\
\hline (5) $\mathrm{C}_{3} \mathrm{H}_{5} \mathrm{O}_{3}^{-}+0.5 \mathrm{SO}_{4}^{2-}=\mathrm{C}_{2} \mathrm{H}_{3} \mathrm{O}_{2}^{-}+\mathrm{HCO}_{3}^{-}+0.5 \mathrm{HS}^{-}+0.5 \mathrm{H}^{+}$ & -116 & -41 & 60 \\
\hline (6) $\mathrm{C}_{2} \mathrm{H}_{3} \mathrm{O}_{2}^{-}+\mathrm{SO}_{4}^{2-}=2 \mathrm{HCO}_{3}^{-}+\mathrm{HS}^{-}$ & -102 & -59 & 57 \\
\hline (7) $\mathrm{C}_{3} \mathrm{H}_{5} \mathrm{O}_{3}^{-}+2 \mathrm{~S}^{0}+2 \mathrm{H}_{2} \mathrm{O}=2 \mathrm{HS}^{-}+\mathrm{HCO}_{3}^{-}+\mathrm{C}_{2} \mathrm{H}_{3} \mathrm{O}_{2}^{-}+3 \mathrm{H}^{+}$ & -210 & -172 & \\
\hline (8) $\mathrm{C}_{2} \mathrm{H}_{3} \mathrm{O}_{2}^{-}+4 \mathrm{~S}^{0}+4 \mathrm{H}_{2}^{-} \mathrm{O}=4 \mathrm{HS}^{-}+2 \mathrm{HCO}_{3}^{-}+5 \mathrm{H}^{+}$ & -288 & -322 & \\
\hline
\end{tabular}

Predicted abiotic FeS reactions:

(9) $\mathrm{HS}^{-}+2 \mathrm{Fe}(\mathrm{OH})_{3}+5 \mathrm{H}^{+}=2 \mathrm{Fe}^{2+}+\mathrm{S}^{0}+6 \mathrm{H}_{2} \mathrm{O}$

(10) $\mathrm{HS}^{-}+2 \mathrm{FeOOH}+5 \mathrm{H}^{+}=2 \mathrm{Fe}^{2+}+\mathrm{S}^{0}+4 \mathrm{H}_{2} \mathrm{O}$

(11) $\mathrm{Fe}^{2+}+\mathrm{HS}^{-}=\mathrm{FeS}+\mathrm{H}^{+}$

${ }^{\mathrm{a}}$ Calculated based on the influent conditions: $\mathrm{pH}=7$; $\left[\mathrm{Fe}^{2+}\right]$ and $\left[\mathrm{HS}^{-}\right]=10^{-12} ;\left[\mathrm{C}_{3} \mathrm{H}_{5} \mathrm{O}_{3}^{-}\right]$and $\left[\mathrm{C}_{2} \mathrm{H}_{3} \mathrm{O}_{2}^{-}\right]=5 \times 10^{-4} ;\left[\mathrm{SO}_{4}^{2-}\right]=2 \times 10^{-4}$;

$\left[\mathrm{HCO}_{3}^{-}\right]=6 \times 10^{-3} \mathrm{M}$. Effluent conditions: $\mathrm{pH}=8 ;\left[\mathrm{Fe}^{2+}\right]=10^{-4}$; [HS- $]=10^{-12} ;\left[\mathrm{SO}_{4}^{2-}\right]=2 \times 10^{-12} ;\left[\mathrm{C}_{3} \mathrm{H}_{5} \mathrm{O}_{3}^{-}\right]=10^{-12} ;\left[\mathrm{C}_{2} \mathrm{H}_{3} \mathrm{O}_{2}^{-}\right]=4 \times 10^{-3} \mathrm{M}^{\mathrm{c}} \Delta G_{\mathrm{f}}^{0} \mathrm{values}^{-}$ for two-line ferrihydrite nominally as $\mathrm{Fe}(\mathrm{OH})_{3}$ (Majzlan et al., 2004) or $\mathrm{FeOOH}^{*} 0.027 \mathrm{H}_{2} \mathrm{O}$ (Snow et al., 2013) and goethite $(\alpha-\mathrm{FeOOH})(\mathrm{Majzlan}$ et al., 2003) were $-705,-473$ and $-489 \mathrm{~kJ} \mathrm{~mol}^{-1}$, respectively. ${ }^{\mathrm{d}} \Delta G_{\mathrm{u}}=\Delta G_{\mathrm{r}}-m \Delta G_{\mathrm{p}}$, where $\Delta G_{\mathrm{p}}=45 \mathrm{~kJ}$ (mol ATP) ${ }^{-1}$ and $m$ (ATP number) for sulfate reduction is 1 and 5/4 for acetrotrophic Fe(III) reduction. The same $m$ value was used for lactate.

\begin{tabular}{|c|c|c|c|c|c|c|c|}
\hline & & & Control & $\mathrm{Fh}$ & $\mathrm{Al}-\mathrm{Fh}$ & Gt & $\mathrm{Hm}$ \\
\hline$\uparrow$ & 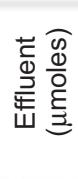 & $\begin{array}{c}\text { Lactate } \\
\text { Acetate } \\
\text { Sulfate } \\
\text { HS }^{-}{ }_{(\mathrm{aq})} \\
\mathrm{Fe}(\mathrm{II})_{\mathrm{aq}}\end{array}$ & $\begin{array}{c}48 \\
2947 \\
2 \\
165 \\
1\end{array}$ & $\begin{array}{c}31 \\
3320 \\
2 \\
1 \\
208\end{array}$ & $\begin{array}{c}25 \\
2130 \\
2 \\
1 \\
135\end{array}$ & $\begin{array}{c}39 \\
2597 \\
3 \\
8 \\
38\end{array}$ & $\begin{array}{c}30 \\
1253 \\
2 \\
3 \\
33\end{array}$ \\
\hline 은 & 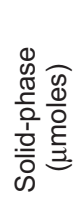 & $\begin{array}{r}\text { Sulfide } \\
\mathrm{Fe}(\mathrm{II}) \\
\\
\text { Sulfide } \\
\mathrm{Fe}(\mathrm{II})\end{array}$ & $\begin{array}{l}3 \\
2\end{array}$ & $\begin{array}{c}1 \\
563 \\
\\
\\
119 \\
652\end{array}$ & $\begin{array}{c}2 \\
787 \\
\\
\\
145 \\
648\end{array}$ & \begin{tabular}{c|c}
4 \\
18 \\
\\
\\
\\
134 \\
231
\end{tabular} & $\begin{array}{c}0 \\
50 \\
\\
\\
132 \\
221\end{array}$ \\
\hline & 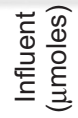 & $\begin{array}{l}\text { Lactate } \\
\text { Acetate } \\
\text { Sulfate }\end{array}$ & $\begin{array}{l}664 \\
664 \\
205\end{array}$ & $\begin{array}{l}621 \\
621 \\
248\end{array}$ & $\begin{array}{l}558 \\
558 \\
223\end{array}$ & $\begin{array}{l}547 \\
547 \\
219\end{array}$ & $\begin{array}{l}500 \\
500 \\
200\end{array}$ \\
\hline
\end{tabular}

Figure 1 Geochemical characteristics of the influent, effluent and solid-phase and microbial community composition within the 19 days incubated unamended (control) and iron oxide-amended columns. The components are shown as cumulative concentrations within each pool following the first 19 days of incubation (data are tabulated in Supplementary Table 1). Solid-phase Fe(II) and sulfide are total concentrations of these components associated with the solid-phase measured via colorimetric analysis of solid extracts. Flow goes from the bottom (upgradient) to top (downgradient) of the column. Secondary mineralization is evident by the conversion of red ferrihydrite, yellow goethite and red hematite to black iron sulfides and magnetite (ferrihydrite only; see Supplementary Figure 1).

(Figure 1 and Supplementary Table 1), suggesting that $\mathrm{Fe}(\mathrm{III})$ reduction was primarily mediated by iron oxide reaction with hydrogen sulfide (that is, sulfidization). Despite ample acetate flowing through the column (Figure 2), the limited ability of model iron-reducing bacteria to reduce crystalline $\mathrm{Fe}$ oxides like goethite and hematite likely precluded their activity (Hansel et al., 2004; Cutting et al., 2009).

Although reduction of these crystalline phases can occur co-metabolically by fermenting organisms
(Dobbin et al., 1999; Dominik et al., 2002), it appears that the consumption of lactate (Figure 2) by sulfatereducing bacteria and lack of other fermentable substrates limited their activity here and supported a smaller relative proportion of putative fermenting organisms (Figure 3 and Supplementary Table 2). Further, lower carbon concentrations have previously been shown to select for sulfate-reducing over fermenting microbial populations (Oyekola et al., 2009). However, as sulfate reducers can utilize a wide range of fermentation products, we cannot rule out 

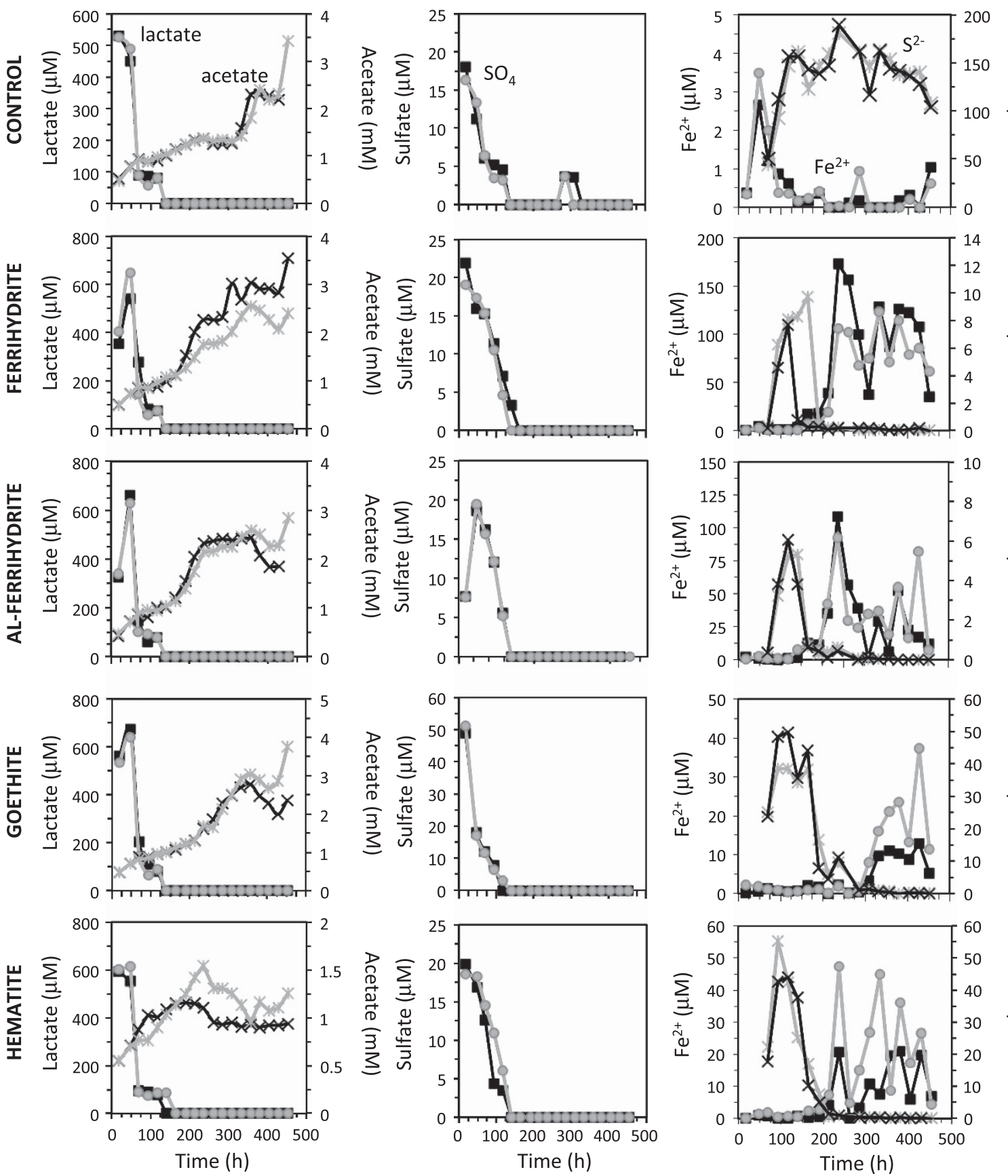

Figure 2 Aqueous chemistry of the column effluent, including (left) lactate and acetate, (middle) sulfate and (right) ferrous iron and sulfide concentrations over time. All columns were conducted in duplicate with one set terminated after 19 days (gray) and the other at 29 days (black) to analyze for solid-phase and microbiological composition. Acetate production is non-stoichiometric with lactate consumption and increases steadily over time, evidence of acetogenesis within the column. This is supported by observations of substantial $16 \mathrm{~S}$ rRNA sequences for the acetogen Acetobacterium within the columns. Note the different scales for the $y$-axis and that all concentrations are $\mu \mathrm{m}$ except for acetate, which is mм.

that fermenting organisms were (also) consuming lactate and subsequently fed the sulfate-reducing population (Rabus et al., 2006). We predict that the fermenting population was contributing to iron reduction but was likely quantitatively minor in comparison to reduction by sulfide. Thus, in the presence of only lactate and acetate, goethite and hematite reduction were primarily a byproduct of 'sulfidization' driven by the activity of sulfate-reducing bacteria.
In keeping with these energetic predictions (Table 1), it should then follow that the reduction of more reactive $\mathrm{Fe}(\mathrm{III})$ (hydr)oxides, and specifically the poorly crystalline Fe hydroxide ferrihydrite, should support and actually preferentially select for iron-respiring communities. Specifically, at the environmental conditions within the influent section of the column, ferrihydrite reduction is thermodynamically predicted to outcompete sulfate reduction 


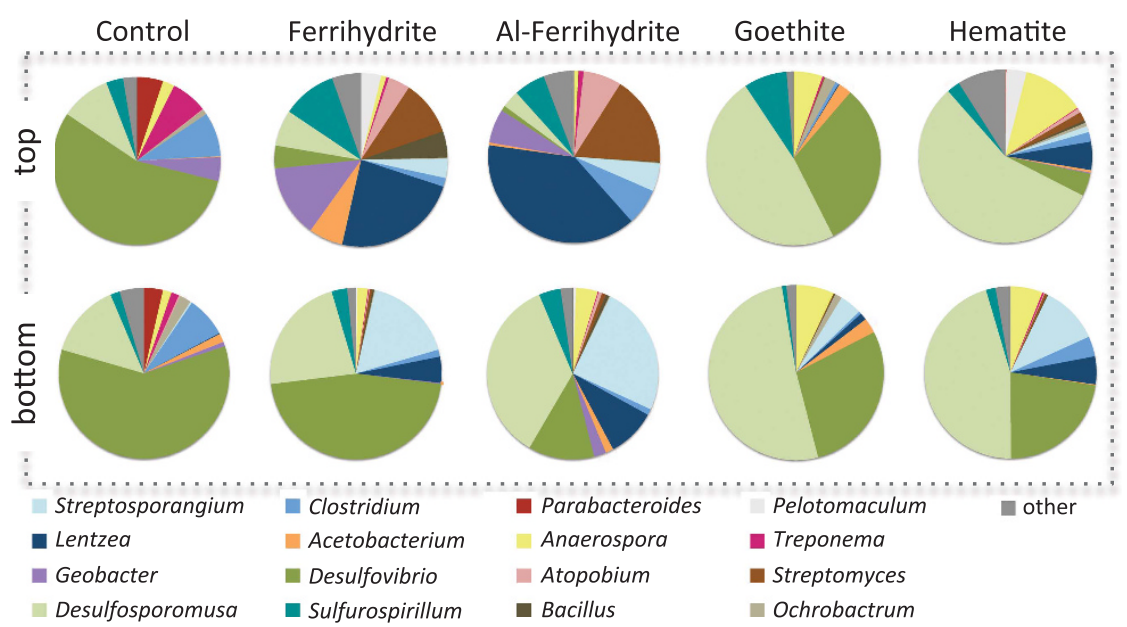

Figure 3 Microbial community composition within the sediments in the unamended (control) and iron oxide-amended columns after 19 days of incubation. There were 16 genus-level taxonomic groups that had $2 \%$ or greater representation in the $16 \mathrm{~S}$ rRNA sequence libraries for any of the samples. Genera representing less than $2 \%$ of the sequence libraries were grouped together and labeled as 'other.' Pie graphs display these 16 genera for the sediments from the top and bottom of the columns. Dominant and key functional groups include sulfate-reducing Desulfovibrio and Desulfosporomusa, iron-reducing Geobacter, sulfur-reducing Sulfurospirillum sp. and fermenters Clostridia and Lentzea spp. Tabulated values for these samples and the initial sediment are provided in Supplementary Table 2.

for lactate or acetate (Table 1). However, similar to the goethite columns, sulfate (and lactate) was completely consumed within the ferrihydrite columns (Figures 1 and 2,). Further, as seen with the more crystalline iron oxides, sulfide was observed in the effluent of the ferrihydrite columns within a few days (Figure 2), indicating that sulfate reduction was stimulated immediately upon addition of carbon.

Consequently, the upgradient sections of the ferrihydrite columns are strikingly similar to the goethite and hematite columns, as seen by the high $\mathrm{FeS}$ concentrations and overwhelming dominance ( $>70 \%$ for $\mathrm{Fh} ; \sim 50 \%$ for $\mathrm{Al}-\mathrm{Fh}$ ) of the lactateoxidizing, sulfate-reducing (Desulfovibrio and Desulfosporomusa) genera (Figures 1 and 3, Supplementary Tables 1 and 2). We cannot rule out the possibility that these organisms were also directly reducing ferrihydrite, and, in fact, some Desulfovibrio species can respire ferric iron (Coleman et al., 1993; Li et al., 2006). Yet, sulfate was still completely consumed in the columns (Figure 2) and sulfide was extensively sequestrated in the solid-phase along the beginning of the flowpath (Figure 1 and Supplementary Table 1). Further, known iron-reducing bacterial genera (Lovley et al., 2004; Weber et al., 2006) were minor ( $2 \%$ in $\mathrm{Al}-\mathrm{Fh}$ ) or completely absent (Fh) within the sediments along the initial flowpath after 19 days, despite previous observations of both lactate- and acetate-oxidizing iron reducers in the sediments (Lentini et al., 2012; Lentini, 2013). Thus, sulfate reduction was a primary means of carbon oxidation within the beginning of ferrihydrite columns despite the presence of ample acetate and the more energetically favorable phase ferrihydrite to support canonical iron respiration (Lovley and Phillips, 1988).
Consumption of sulfate and lactate upgradient led to a transition from sulfate to $\mathrm{Fe}$ (III) reduction, presumably via iron respiration, within the ferrihydrite columns. In contrast to the goethite and hematite columns, solid-phase Fe(II) was detected throughout the column (Figure 1 and Supplementary Table 1). Fe(II) within the downgradient ironreducing zones within the ferrihydrite columns was coincident with the presence of the common acetateoxidizing, Fe(III)-reducing bacterium, Geobacter $(\sim 14 \%$ for $\mathrm{Fh}$ and $6 \%$ for Al-Fh $16 \mathrm{~S}$ rRNA sequences) and a higher proportion of fermenting organisms (Figure 3 and Supplementary Table 2; Lovley and Phillips, 1988). This transition in the distribution from sulfate- to iron-reducing microbial communities is counterintuitive when considering the reaction energetics along the column gradient. In particular, the reduction of Fe(III) via sulfide (as well as other iron-reducing processes) leads to progressively more alkaline conditions downgradient as observed in the higher $\mathrm{pH}$ of the effluent solution (Supplementary Figure 2). Although the energetics of sulfate reduction is largely insensitive to $\mathrm{pH}$ (Table 1; Postma and Jakobsen, 1996; Bethke et al., 2011; Flynn et al., 2014), higher pH greatly deceases the favorability of iron reduction (Table 1). Nevertheless, sulfate-reducing organisms, which presumably have a less energetic metabolism (Table 1 and see Bethke et al., 2011; LaRowe and Van Cappellen, 2011; Postma and Jakobsen, 1996), dominated the microbial communities along the initial flowpath, whereas iron-reducing organisms dominated the less conducive conditions downgradient.

Rather, the activity of the ferrihydrite-reducing communities appears to have been suppressed until sulfate was near quantitatively consumed. Given the eventual presence and activity of iron-reducing 
bacteria (in the absence of sulfate) upgradient, nutrients were clearly not limiting growth or driving competitive exclusion. Thus, even given the presence of Geobacter (Supplementary Table 2) and Shewanella species within the indigenous population (Lentini et al., 2012; Lentini, 2013) and ample acetate (Figure 2,and Supplementary Table 1) and Fe (III) as ferrihydrite (Supplementary Figure 1), classically envisioned dissimilatory iron reduction became the dominant respiratory process only after sulfate reduction ceased.

This suppression of iron respiration may have been a consequence of sulfide toxicity, lower iron oxide availability through sulfidization, and/or other unappreciated constraints on the metabolism of solid-substrates (Burdige 1993; Koretsky et al., 2003). An unexpected oscillatory behavior of ironand sulfate-reducing organisms was previously observed in batch incubations containing saltmarsh sediments, where carbon-stimulated activity of sulfate-reducing organisms led to suppression of microbial iron respiration (Koretsky et al., 2003). Addition of exogenous ferrihydrite did not stimulate dissimilatory iron-reducing communities or depress sulfate reduction rates, suggesting that sulfide toxicity rather than diminished iron oxide availability was responsible for the inhibitory effect. Here, sulfate reduction commenced at the onset of carbon addition when ferrihydrite bioavailability was high and sulfide levels were low. Further, although the ferrihydrite surface likely became compromised by secondary precipitates over time, nearly half of the ferrihydrite was still present in the columns after 19 days (Supplementary Figure 1). This ferrihydrite was still chemically reactive toward sulfide, as sulfide was not detected in the effluent and in minor levels downgradient (Figures 1 and 2). Although we can only speculate at this point, we predict that the proliferation of sulfate reducers at inception here is a consequence of differences in kinetic constraints on electron transfer reactions to solid-phase versus soluble substrates.

This microbial respiratory sequence (Figure 3) and solid-phase distribution (Figure 1) point to reactions with free sulfide largely driving initial iron redox transformations in the presence of iron oxides regardless of the structure and despite low sulfate levels ( $<1 \%$ modern ocean). It is well established that sulfidization, abiotic reaction of sulfide $\left(\mathrm{HS}^{-}\right)$and iron oxides, leads to iron reduction and formation of intermediate sulfur species such as elemental sulfur $\left(S^{0}\right)$ (Poulton, 2003). In detail, one can assume that each mole of biogenic sulfide generated reacts with ferrihydrite, for instance, to produce two moles of $\mathrm{Fe}$ (II) (Table 1). Using this stoichiometry and assuming the FeS pool represents immediately sequestered sulfide, we estimate that $\mathrm{Fe}(\mathrm{II})$ produced via reaction with free sulfide formed through solely sulfate reduction accounts for $39 \%$ and $54 \%$ of the total $\mathrm{Fe}$ (II) generated in the upgradient section of the ferrihydrite column and throughout the entire

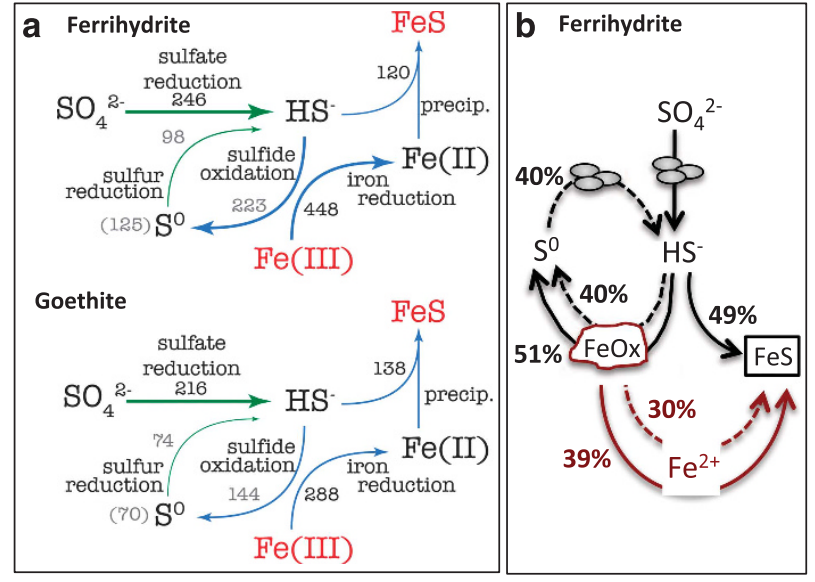

Figure 4 (a) Schematic representing cumulative fluxes of compounds (also denoted by line weight of arrows) as measured in flow-through column experiments using sediments amended with either ferrihydrite or goethite. Values shown in black are the cumulative fluxes (in $\mu \mathrm{mol}$ ) measured at the end of the experiment (sulfate reduction measured as sulfate consumed, iron reduction measured as change in total $\mathrm{Fe}(\mathrm{II})$ and $\mathrm{FeS}$ precipitation measured as acid volatile sulfide). Values in gray are sulfur transformation fluxes calculated to satisfy iron mass balance. In both ferrihydrite and goethite, sulfur mass balance implies an unmeasured intermediate sulfur pool of 125 and $70 \mu \mathrm{mol}$, respectively. (b) Using the fluxes in a, the relative importance of recycling of an intermediate sulfur pool (dashed lines) in catalyzing iron reduction for ferrihydrite is calculated. Numbers in black reflect mass fluxes normalized to the amount of sulfate reduced. Based on the difference between sulfate reduced (SR) and sulfide recovered as $\mathrm{FeS}$, a minimum of $51 \%$ of residual SR-derived sulfide reacted with ferrihydrite yielding sulfur of an intermediate oxidation state (predicted as $\mathrm{S}^{\circ}$ ). A ratio of $\mathrm{Fe}(\mathrm{II})$ produced to sulfate reduced of 2.9:1 was applied to calculate the amount of $S^{0}$ reduction required to satisfy the iron mass balance (representing approximately $40 \%$ of the sulfate originally reduced). This recycling, which leads to a standing pool of $\mathrm{S}^{0}$ (interpreted as the sulfur not accountable as sulfate or sulfide), implies that an equivalent of $91 \%$ of the original sulfate reduced was directly involved in iron reduction. Numbers in red indicate the relative proportion of Fe(III) reduced by sulfide derived from sulfate reduction (solid lines) or from $\mathrm{S}^{0}$ reduction (dashed lines).

goethite column, respectively (Figure 4 and Supplementary Table 1). Thus, by the most conservative estimate, nearly $40 \%$ of the iron reduction in the upgradient sections of the ferrihydrite columns can be attributed solely to reaction with biogenically derived sulfide through sulfate reduction.

However, we observed ratios of Fe(II) to sulfide (tracked by sulfide accumulation and sulfate loss) in excess of 2, which implicates an additional mechanism for production of $\mathrm{Fe}(\mathrm{II})$. At first pass, the additional $\mathrm{Fe}(\mathrm{III})$ reduction might suggest classic dissimilatory iron reduction. The dominance of sulfate-reducing bacteria and absence of known iron-reducing populations within the goethite and hematite columns and bottom of the ferrihydrite columns, however, point to other ferrous iron sources (Figures 1 and 3, Supplementary Table 2). We cannot rule out the presence of unknown ironreducing organisms or that known iron-reducing organisms were also initially present with the sulfate-reducing organisms, but then preferentially 


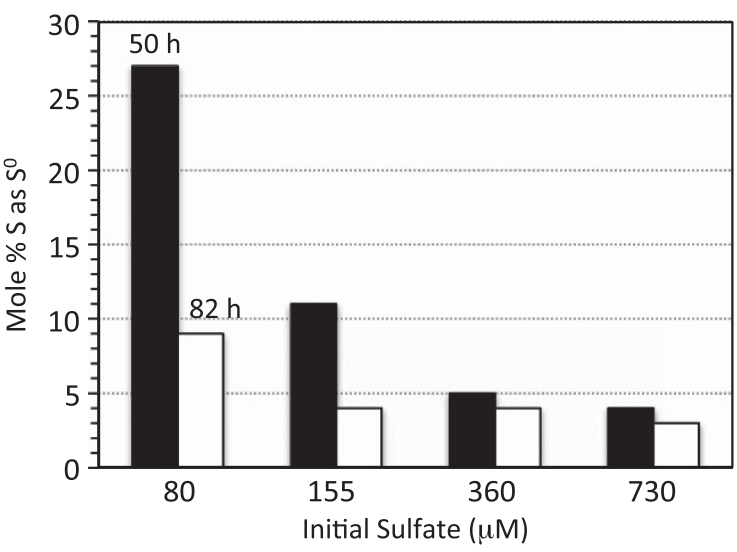

Figure 5 Sulfur XANES from batch incubations. Mole percent of sulfur present as elemental sulfur within the batch incubations containing $D$. putealis and two-line ferrihydrite after $50 \mathrm{~h}$ (black bars) and $82 \mathrm{~h}$ (white bars) as a function of initial sulfate concentration $(80-730 \mu \mathrm{M})$. S(0) percentages were obtained from linear combination fitting of S K-edge XANES spectra using a set of standard spectra over the energy range $2465-2495 \mathrm{eV}$. $R$ values (Newville, 2001) range from 0.002 to 0.01 .

died off and their DNA degraded and/or washed out of the column. Nevertheless, an incomplete sulfur mass balance based on the offset of sulfate introduced to total sulfide measured indicates that there was a standing pool of intermediate sulfur species within both the more crystalline $(63-70 \mu \mathrm{mol} S$ for goethite and hematite) and poorly crystalline iron oxide (103-125 umol S for pure and Al-ferrihydrite) columns (Supplementary Table 1 and Figure 4). This is in stark contrast to the unamended control columns, where we had a largely (>95\%) resolved sulfur mass balance (see Supplementary Table 1). Although DOM can also oxidize sulfide to various sulfur intermediates (including thiosulfate) in anoxic systems (Heitmann and Blodau, 2006), since the control columns also contained the same starting sediment inoculum, DOM-mediated formation of sulfur intermediates cannot (fully) explain this mass balance difference.

Instead, we predict that sulfide oxidation and the subsequent re-reduction of intermediate sulfur species, defined here as $S^{0}$ (elemental sulfur), were likely responsible for the majority of the additional Fe(III) reduction; in essence, a cryptic sulfur cycle as proposed previously in sub-glacial and marine systems (Mikucki et al., 2009; Holmkvist et al., 2011). In parallel to the column experiments, batch incubations conducted under equivalent geochemical conditions enriched for sulfate reducers closely related to the dominant species identified within the columns (Desulfovibrio putealis and D. vulgaris; Lentini et al., 2012; Lentini, 2013). Batch incubation of these axenic cultures with ferrihydrite and at sulfate levels mimicking the column influent led to the same sulfidization reactions as identified in the column experiments-that is, reduction of Fe(III) by $\mathrm{HS}^{-}$and FeS precipitation (Figure 4 and Table 1). Within these batch incubations, elemental $S$ was a

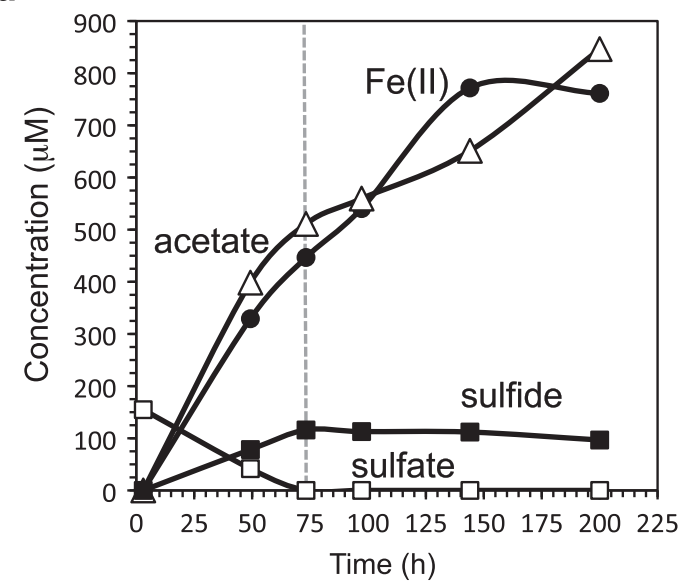

b

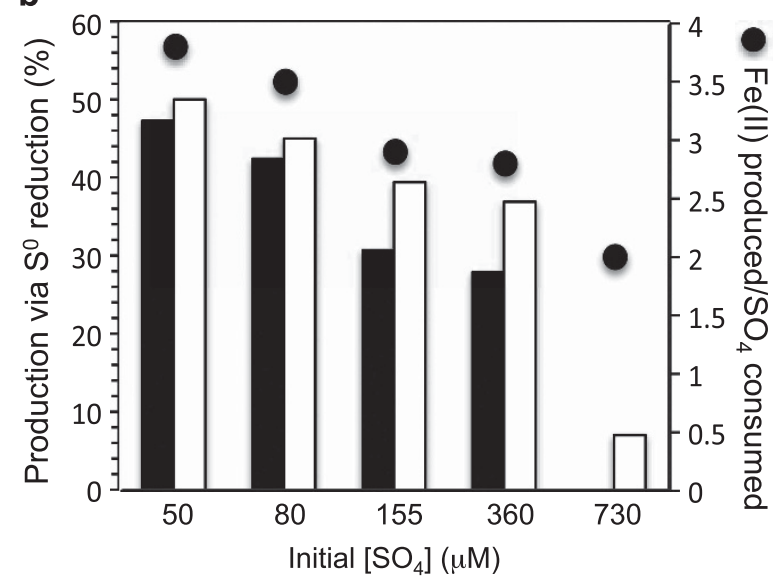

Figure 6 Sulfide-driven ferrihydrite reduction mediated by Desulfovibrio putealis in batch reactors. (a) Continued total Fe(II) (closed circles) and acetate (open triangles) production following complete consumption of $155 \mu \mathrm{M}$ sulfate (open squares; vertical dotted line) implicates recycling of intermediate sulfur species. Indeed, approximately one-quarter (са $40 \mu \mathrm{M}$ ) of the sulfate reduced is not accounted for in the total sulfide pool (closed squares). A large fraction of this missing pool is present as transient $S^{0}$ species (Figure 5). In the presence of ferrihydrite but absence of sulfate, maximum Fe(II) levels are $10 \mu \mathrm{M}$ and acetate is below detection limit indicating that $D$. putealis does not have the ability to respire ferrihydrite. (b) Black circles indicate the ratio of $\mathrm{Fe}(\mathrm{II})$ generated to initial sulfate concentration (Fe(II): $\mathrm{SO}_{4}$ ) as a function of sulfate concentration. Deviation from a ratio of 2 indicates more $\mathrm{Fe}(\mathrm{II})$ was generated than can be supported by all sulfate-derived $\mathrm{HS}^{-}$reaction with the iron hydroxide. Based on this deviation, the bars indicate the proportion of total Fe(II) (black bars) and acetate (open bars) produced due to $S^{0}$ reduction as a function of initial sulfate concentration after $73 \mathrm{~h}$ of reaction (time point at which all sulfate is depleted). Equivalent results were obtained for $D$. vulgaris.

observed as a reaction product of sulfide reaction with ferrihydrite (Table 1 and Figure 5), which can be metabolized by these Desulfovibrio species (Rabus et al., 2006). In fact, at initial sulfate concentrations similar to those in the influent solution used in the columns $(\sim 150 \mu \mathrm{M})$, acetate and Fe(II) were still generated following complete consumption of sulfate (Figure 6a) and coincident with the loss of $S^{0}$ (Figure 5). Thus, sulfide regenerated through the 
microbial reduction of $\mathrm{S}^{0}$ (Table 1) coupled to further lactate oxidation led to sulfide-generated $\mathrm{Fe}(\mathrm{II})$ in excess of the presumed Fe:S for sulfate reduction of 2 (Figure $6 \mathrm{~b}$ and Table 1). This recycling, in fact, can account for nearly half of the Fe(III) reduced within these batch experiments (Figure 6b).

This sulfur recycling at an initial sulfate concentration of $150 \mu \mathrm{M}$ led to a ratio of generated Fe(II) to sulfate reduction near 3 (rather than 2; Figure 6b), which is notably similar to that observed in the iron oxide column experiments (Figure 1 and Supplementary Table 1). Within the ferrihydrite columns, we applied this batch-derived $\mathrm{Fe}(\mathrm{II}) / \mathrm{SO}_{4}$ stoichiometry to calculate the amount of $\mathrm{S}^{0}$ reduction required to satisfy the iron mass balance (Figure 4a). The amount of sulfide oxidation was then calculated as the sum of $S^{0}$ reduction plus the standing pool of $S^{0}$ (interpreted as the sulfur not accountable as sulfate or sulfide). Using this approach, then nearly $70 \%$ of the total Fe(II) within the upgradient section of the ferrihydrite column can be explained without calling upon the activity of iron-respiring populations (Figure 4b). For comparison, within the goethite columns, the amount of sulfide oxidation was constrained by iron mass balance and was simply calculated as the amount required to produce enough sulfide to produce the observed Fe(II) (Figure 4a). As we have excluded the measured FeS-associated sulfur pool in any recycling for these models (Figure 4), we contend that this is likely an underestimate of the sulfur-based iron reduction. In any case, it is clear that sulfate reduction, cryptic $\mathrm{S}$ cycling and the inorganic reduction of $\mathrm{Fe}(\mathrm{III})$ by biogenic sulfide was a dominant process in the $\mathrm{Fe}$ cycle within these ferrihydrite-dominated, low-sulfate systems.

In addition to the mass balance calculations (Figure 4 and Supplementary Table 1), the presence of sulfur intermediates is further supported through taxonomic indicators. In particular, a substantial fraction (up to 10\%) of the $16 \mathrm{~S}$ rRNA sequences within the iron oxide-amended columns belonged to Sulfurospirillum (Figure 3 and Supplementary Table 2), a bacterium known to couple the oxidation of lactate to the reduction of intermediate $\mathrm{S}$ species like $S^{0}$ (but not sulfate; Straub and Schink, 2004). Indeed, within pure culture batch incubations, this bacterium previously demonstrated extensive ferrihydrite reduction via a catalytic sulfur cycle that resulted in sustained respiration of intermediate sulfur species (mostly $\mathrm{S}^{0}$ but also sulfite, tetrathionate and polysulfides (Lohmayer et al., 2014)) and recycling (>60 times) of sulfur (Straub and Schink, 2004). In our sediment columns, the initial oxidation of biogenic HS $^{-}$coupled to $\mathrm{Fe}(\mathrm{III})$ reduction generated $\mathrm{S}^{0}$ and likely other sulfur intermediates, which could then be recycled back to sulfide by both Sulfurospirillum and Desulfovibrio species coupled to lactate oxidation (as in Figures 4,5,6).

Further, although counterintuitive, the relative importance of ferrihydrite reduction via sulfur recycling increased with decreasing sulfate concentration (Figure 6b). That is, the relative role of $S^{0}$ reduction and eventual excess of $\mathrm{Fe}(\mathrm{II})$ production showed an inverse relationship with initial sulfate concentration (Figure 6b). Thus, low-sulfate levels will lead to a disproportionately large amount of $\mathrm{Fe}$ (III) reduction by cryptic $\mathrm{S}$ cycling. As the bacterial communities within the columns were dominated by these two genera (Desulfovibrio and Sulfurospirillum; Figure 3 and Supplementary Table 2), we contend that it can be safely assumed that intermediate sulfur species like $S^{0}$ played a similar role as reactive intermediates within the sediment columns explored here.

\section{Conclusions}

There is mounting indirect evidence pointing to a sulfur-fueled iron cycle not only within marine sediments (Koretsky et al., 2003; Holmkvist et al., 2011) but also terrestrial systems that span acidic to alkaline conditions (Akob et al., 2008; Komlos et al., 2008; Pester et al., 2012; Osorio et al., 2013; Flynn et al., 2014; Kwon et al., 2014). Previous models of geochemical zonation have likely overlooked the importance of this cryptic cycling by relying primarily on measurements of substrate and endproduct concentrations. In particular, a rapidly spinning cycle involving the consumption of sulfide via reaction with iron oxides and microbial respiration of the subsequent sulfur products (sulfate, sulfur, thiosulfate) leads to low sulfate and aqueous sulfide levels but high Fe(II) conditions that would suggest ferric iron respiration and not sulfur metabolism. By measuring production and consumption rates of metabolic substrates and products, detecting the oftentimes elusive intermediates and monitoring active metabolic pathways, the relevance of these cryptic cycles, involving various elements, within environmental systems will continue to emerge.

Observations of sulfate reduction and cryptic sulfur cycling in natural systems have frequently been attributed to the presence of more crystalline iron oxides that were presumed to be biologically unavailable. Our conservative estimates here indicate that along the upgradient portions of the column where both sulfate and ferrihydrite were available, reaction of ferrihydrite and biogenic sulfide accounted for nearly $40 \%$ of the observed iron reduction, with an additional $30 \%$ if sulfur recycling is invoked. Thus, this research shows that within natural sediments incubated under conditions mimicking natural systems, sulfur-fueled iron reduction is a dominant process regardless of the iron oxide present, including the most bioavailable iron oxide two-line ferrihydrite, and despite low-sulfate levels. In fact, even after 19 days of incubation, more than half of the added ferrihydrite was still present, indicating that observations of sulfate reduction within natural sediments do not necessarily 
preclude the presence of poorly crystalline and microbially available iron oxide phases.

This respiratory sequence, where sulfate reduction precedes or occurs simultaneously with ferrihydrite reduction, leads to an inverse redox zonation that is in stark contrast to long-standing thermodynamic models (Chapelle and Lovley, 1992). Thus, regardless of the mechanistic underpinning, a thermodynamic-based hierarchy cannot alone predict operative respiratory pathways and geochemical zonation in nature. One complicating factor is the frequent utilization of bulk aqueous chemical conditions in thermodynamic models, which most likely do not accurately reflect the biogeochemistry of sedimentary microenvironments. Micro-scale heterogeneity will no doubt hinder our ability to accurately calculate true in situ reaction energetics. It cannot be ruled out therefore that micro-scale porewater heterogeneity leads to localized conditions that favor metabolic reactions not predicted by bulk geochemistry.

By relaxing the presumed energy-based hierarchy between iron- and sulfate-reducing communities, reinterpretation of environmental geochemical zonation will undoubtedly bring to light an overlooked control of kinetic, physiological and ecological factors in the cycling of iron and sulfur. Indeed, the dominance of a microbial Fe cycle has been long assumed for Earth's earliest records (Canfield, 2005), both before and after the initial rise of atmospheric oxygen. This was always taken to reflect an excess of iron over other, more oxygen-dependent, electron acceptors like sulfate. The results presented here, however, indicate that even micromolar levels of Archean sulfate (Halevy, 2013) could catalyze largescale iron cycling-no longer then can evidence for active iron cycling be viewed independent of the sulfur cycle. These findings also challenge certain biogeochemical models predicated on the classic redox tower, perhaps helping to explain the persistence of a prominent Fe redox cycle throughout the Proterozoic (Planavsky et al., 2011) in the face of higher $\mathrm{pO}_{2}$, rather than requiring an excess of ferric iron or paucity of organic carbon or sulfate (Johnston et al., 2010). As ferrihydrite is a dominant product of iron oxidation in the rhizosphere of terrestrial and wetland plants (Emerson et al., 1999; Hansel et al., 2001), this Fe oxide-based sulfur recycling could also explain unexpectedly high rates of sulfate reduction within low-sulfate wetland sediments (see Pester et al. (2012))—systems that single-handedly account for up to $40 \%$ of global emissions of methane (Wuebbles and Hayhoe, 2002). That noted, given this updated understanding of the nature of this system, direct tests should follow. What is clear is that sulfur recycling is an essential catalytic engine driving the Fe cycle.

\section{Conflict of Interest}

The authors declare no conflict of interest.

\section{Acknowledgements}

We appreciate the thoughtful and detailed comments by Dr David Fike and two anonymous reviewers that greatly improved this manuscript. This study was supported by the Strategic Environmental Research and Development Program (SERDP) under grant number ER-2130 and the Department of Energy's Biological and Environmental Research (DOE-BER) program under grant ER65259. The data reported in this paper are tabulated in the Supporting Online Material.

\section{References}

Akob DM, Mills HJ, Gihring TM, Kerkhof L, Stucki JW, Chin K-J et al. (2008). Functional diversity and electron donor dependence of microbial populations capable of $\mathrm{U}(\mathrm{VI})$ reduction in radionuclide contaminated subsurface sediments. App Environ Microb 74: 3159-3170.

Benner SG, Hansel CM, Wielinga BW, Barber TM, Fendorf S. (2002). Reductive dissolution and biomineralization of iron hydroxide under dynamic flow conditions. Environ Sci Technol 36: 1705-1711.

Bethke CM, Sanford RA, Kirk MF, Jin QS, Flynn TM. (2011). The thermodynamic ladder in geomicrobiology. Am J Sci 311: 183-210.

Burdige DJ. (1993). The biogeochemistry of manganese and iron reduction in marine-sediments. Earth Sci Rev 35: 249-284.

Canfield DE. (2005). The early history of atmospheric oxygen: Homage to Robert M. Garrels. Ann Rev Earth Planet Sci 33: 1-36.

Canfield DE, Stewart FJ, Thamdrup B, De Brabandere L, Dalsgaard T, DeLong EF et al. (2010). A cryptic sulfur cycle in oxygen-minimum-zone waters off the Chilean coast. Science 330: 1375-1378.

Caporaso JG, Kuczynski J, Stombaugh J, Bigginger K, Bushman FD, Costello EK et al. (2010). QIIME allows analysis of high-throughput community sequencing data. Nat Methods 7: 335-336.

Champ DR, Gulens J, Jackson RE. (1979). Oxidationreduction sequences in ground water flow systems. Can J Earth Sci 16: 12-23.

Chapelle FH, Lovley DR. (1992). Competative exclusion of sulfate reduction by Fe(III)-reducing bacteria: A mechanism for producing discrete zones of high-iron ground water. Groundwater 30: 29-36.

Cline JD. (1969). Spectrophotometric determination of hydrogen sulfide in natural waters. Limnol Oceanogr 14: 454-45.

Coleman ML, Hedrick DB, Lovley DR, White DC, Pye K. (1993). Reduction of Fe(III) in sediments by sulfatereducing bacteria. Nature 361: 436-438.

Cutting RS, Coker VS, Fellowes JW, Lloyd JR, Vaughan DJ. (2009). Mineralogical and morphological constraints on the reduction of Fe(III) minerals by Geobacter sulfurreducens. Geochim Cosmochim Acta 73: 4004-4022.

DeSantis TZ, Hugenholtz P, Larsen N, Rojas M, Brodie EL, Keller K et al. (2006). Greengenes, a chimera-checked $16 \mathrm{~S}$ rRNA gene database and workbench compatible with ARB. Appl Environ Microbiol 72: 5069-5072.

Dobbin PS, Carter JP, Garcia-Salamanca San Juan C, von Hobe M, Powell AK, Richardson DJ. (1999). Dissimilatory $\mathrm{Fe}(\mathrm{III})$ reduction by Clostridium 
beijerinckii isolated from freshwater sediment using Fe (III) maltol enrichment. FEMS Microb Lett 176: 131-138.

Dominik P, Pohl H, Bousserrhine N, Berthelin J, Kaupenjohann M. (2002). Limitations to the reductive dissolution of Al-substituted goethites by Clostridium butyricum. Soil Biol Biochem 34: 1147-1155.

Dowd S, Callaway T, Wolcott R, Sun Y, McKeehan T, Hagevoort R et al. (2008). Evaluation of the bacterial diversity in the feces of cattle using $16 \mathrm{~S}$ rDNA bacterial tag-encoded FLX amplicon pyrosequencing (bTEFAP). BMC. Microbiology 8: 125.

Edgar RC, Haas BJ, Clemente JC, Quince C, Knight R. (2011). UCHIME improves sensitivity and speed of chimera detection. Bioinformatics 27: 2194-2200.

Elsgard L, Jorgensen BB. (1992). Anoxic transformations of radiolabeled hydrogen sulfide in marine and freshwater sediments. Geochim Cosmochim Acta 56: 2425-2435.

Emerson D, Weiss JV, Megonigal JP. (1999). Iron-oxidizing bacteria are associated with ferric hydroxide precipitates (Fe-plaque) on the roots of wetland plants. Appl Environ Microbiol 65: 2758-2761.

Flynn TM, O'Loughlin EJ, Mishra B, DiChristina TJ, Kemner KM. (2014). Sulfur-mediated electron shuttling during bacterial iron reduction. Science 344: 1039-1042.

Froelich PN, Klinkhammer GP, Bender ML, Luedtke NA, Heath GR, Cullen D et al. (1979). Early oxidation of organic matter in pelagic sediments of the eastern equatorial Atlantic: Suboxic diagenesis. Geochim Cosmochim Acta 43: 1075-1090.

Halevy I. (2013). Production, preservation, and biological processing of mass-independent sulfur isotope fractionation in the Archean surface environment. Proc Natl Acad Sci USA 110: 17644-17649.

Hansel CM, Fendorf S, Sutton SR, Newville M. (2001). Characterization of Fe plaque and associated metals on the roots of mine-waste impacted aquatic plants. Environ Sci Technol 35: 3863-3868.

Hansel CM, Benner SG, Neiss J, Dohnalkova A, Kukkadapu RK, Fendorf S. (2003). Secondary mineralization pathways induced by dissimilatory iron reduction of ferrihydrite under advective flow. Geochim Cosmochim Acta 67: 2977-2992.

Hansel CM, Benner SG, Nico P, Fendorf S. (2004). Structural constraints of ferric (hydr)oxides on dissimilatory iron reduction and the fate of $\mathrm{Fe}(\mathrm{II})$. Geochim Cosmochim Acta 68: 3217-3229.

Heitmann T, Blodau C. (2006). Oxidation and incoporation of hydrogen sulfide by dissolved organic matter. Chem Geol 235: 12-20.

Hoehler TM, Alperin MJ, Albert DB, Martens CS. (1998). Thermodynamic control on hydrogen concentrations in anoxic sediments. Geochim Cosmochim Acta 62: 1745-1756.

Holmkvist L, Ferdelman TG, Jorgensen BB. (2011). A cryptic sulfur cycle driven by iron in the methane zone of marine sediment (Aarhus Bay, Denmark). Geochim Cosmochim Acta 75: 3581-3599.

Jakobsen R, Postma D. (1999). Redox zoning, rates of sulfate reduction and interactions with Fe-reduction and methanogenesis in a shallow sandy aquifer, Romo, Denmark. Geochim Cosmochim Acta 63: 137-151.

Johnston DT, Poulton SW, Dehler C, Porter S, Husson J, Canfield DE et al. (2010). An emerging picture of Neoproterozoic ocean chemistry: Insights from the
Chuar Group, Grand Canyon, USA. Earth Planet Sci Let 290: 64-73.

Jorgensen BB. (1990). A thiosulfate shunt in the sulfur cycle of marine sediments. Science 249: 152-154.

Komlos J, Moon HS, Jaffe PR. (2008). Effect of Sulfate on the Simultaneous Bioreduction of Iron and Uranium. J Environ Qual 37: 2058-2062.

Koretsky CM, Moore CM, Lowe KL, Meile C, Dichristina TJ, Van Cappellen P. (2003). Seasonal oscillation of microbial iron and sulfate reduction in saltmarsh sediments (Sapelo Island, GA, USA). Biogeochem 64: 179-203.

Kwon MJ, Boyanov MI, Antonopoulos DA, Brulc JM, Johnston ER, Skinner KA et al. (2014). Effects of dissimilatory sulfate reduction on Fe-III (hydr)oxide reduction and microbial community development. Geochim Cosmochim Acta 129: 177-190.

LaRowe DE, Van Cappellen P. (2011). Degradation of natural organic matter: A thermodynamic analysis. Geochim Cosmochim Acta 75: 2030-2042.

Lentini CJ, Wankel SD, Hansel CM. (2012). Enriched iron (III)-reducing bacterial communities are shaped by carbon substrate and iron oxide mineralogy. Frontiers in Microbiology 3: 19.

Lentini CJ. (2013). The Role of Fe(III) Oxyhydroxides in Shaping Microbial Communities Capable of Fe(III) Reduction (Doctoral dissertation). Harvard University: Cambridge, MA, USA.

Li Y-L, Vali H, Yang J, Phelps TJ, Zhang CL. (2006). Reduction of iron oxides enhanced by sulfate-reducing bacterium and biogenic H2S. Geomicrob J 23: 103-117.

Lohmayer R, Kappler A, Behrens-Losekann T, Planer-Friedrich B. (2014). Sulfur species as redox partners and electron shuttles for ferrihydrite reduction by Sulfospirillum deleyianum. Appl Environ Microbiol 80: 3141-3149.

Lovley DR, Phillips EJP. (1987). Competitive mechanisms for inhibition of sulfate reduction and methane production in the zone of ferric iron reduction in sediments. Appl Environ Microbiol 53: 2636-2641.

Lovley DR, Phillips EJP. (1988). Novel mode of microbial energy metabolism: Organic carbon oxidation coupled to dissimilatory reduction of iron or manganese. Appl Environ Microb 54: 1472-1480.

Lovley DR, Holmes DE, Nevin KP. (2004). Dissimilatory Fe (III) and Mn(IV) Reduction. Adv Microb Physiol 49: 219-286.

Ludwig W, Mittenhuber G, Friedrich CG. (1993). Transfer of Thiosphaera pantotropha to Paracoccus denitrificans. Int J Syst Bacteriol 43: 363-367.

Majzlan J, Grevel K-D, Navrotsky A. (2003). Thermodynamics of Fe oxides: Part II. Enthalpies of formation and relative stability of goethite (a-FeOOH), lepidocrocite (g-FeOOH), and maghemite (g-Fe2O3). Am Mineral 88: 855-859.

Majzlan J, Navrotsky A, Schwertmann U. (2004). Thermodynamics of iron oxides: Part III. Enthalpies of formation and stability of ferrihydrite $(\sim \mathrm{Fe}(\mathrm{OH}) 3)$, schwertmannite $(\sim \mathrm{FeO}(\mathrm{OH}) 3 / 4(\mathrm{SO} 4) 1 / 8)$, and epsilonFe2O3. Geochimica Et Cosmochimica Acta 68: 1049-1059.

Mikucki JA, Pearson A, Johnston DT, Turchyn AV, Farquhar J, Schrag DP et al. (2009). A Contemporary Microbially Maintained Subglacial Ferrous "Ocean". Science 324: 397-400.

Newville M. (2001). EXAFS analysis using FEFF and FEFFIT. J Synchr Rad 8: 96-100. 
Osorio H, Mangold S, Denis Y, Nancucheo I, Esparza M, Johnson DB et al. (2013). Anaerobic sulfur metabolism coupled to dissimilatory iron reduction in the extremophile Acidithiobacillus ferrooxidans. Appl Environ Microbiol 79: 2172-2181.

Oyekola OO, van Hille RP, Harrison STL. (2009). Competition between lactate oxidisers and fermenters under bisulphidogenic conditions: Implications in the biological treatment of AMD. Adv Mater Res 71: 689-692.

Patrick WH, Henderson RE. (1981). Reduction and reoxidation cycles of manganese and iron in flooded soil and in water solution. Soil Sci Soc Am J 45: 855-859.

Pester M, Knorr KH, Friedrich MW, Wagner M, Loy A. (2012). Sulfate-reducing microorganisms in wetlands fameless actors in carbon cycling and climate change. Front Microbiol 3: 19.

Planavsky NJ, McGoldrick P, Scott CT, Li C, Reinhard CT, Kelly AE et al. (2011). Widespread iron-rich conditions in the mid-Proterozoic ocean. Nature 477: 448-U495.

Postma D, Jakobsen R. (1996). Redox zonation: Equilibrium constraints on the $\mathrm{Fe}(\mathrm{III}) / \mathrm{SO} 4$ - reduction interface. Geochim Cosmochim Acta 60: 3169-3175.

Poulton SW. (2003). Sulfide oxidation and iron dissolution kinetics during the reaction of dissolved sulfide with ferrihydrite. Chem Geol 202: 79-94.

Rabus R, Hansen RA, Widdel F. (2006). Dissimilatory sulfate- and sulfur-reducing prokaryotes. In: Dworkin M (ed) The Prokaryotes: An Evolving Electronic Resource for the Microbiology Community. Springer-Verlag: New York, pp 659-768.
Ruffroberts AL, Kuenen JG, Ward DM. (1994). Distribution of cultivated and uncultivated cyanobacteria and Chloroflexus-like bacteria in hot spring microbial mats. Appl Environ Microbiol 60: 697-704.

Schwertmann U, Cornell RM. (2000). Iron Oxides in the Laboratory: Preparation and Characterization. WileyVCH: NY.

Snow CL, Lilova KI, Radha AV, Shi Q, Smith S, Navrotsky A et al. (2013). Heat capacity and thermodynamics of a synthetic two-line ferrihydrite, $\mathrm{FeOOH}^{*} 0.027 \mathrm{H} 2 \mathrm{O}$. J Chem Thermo 58: 307-314.

Stookey LL. (1970). Ferrozine - a new spectrophotometric reagent for iron. Anal Chem 42: 779-781.

Straub KL, Schink B. (2004). Ferrihydrite-dependent growth of Sulfurospirillum deleyianum through electran transfer via sulfur cycling. App Environ Microb 70: 5744-5749.

Wang Q, Garrity GM, Tiedje JM, Cole JR. (2007). Naive Bayesian classifier for rapid assignment of rRNA sequences into the new bacterial taxonomy. Appl Environ Microbiol 73: 5261-5267.

Webb SM. (2005). SIXPack a graphical user interface for XAS analysis using IFEFFIT. Physica Scripta, T115.

Weber KA, Achenbach LA, Coates JD. (2006). Microorganisms pumping iron: Anaerobic microbial iron oxidation and reduction. Nature 4: 752-764.

Williams KH, Long PE, Davis JA, Wilkins MJ, N'Guessan AL, Steefel CI et al. (2011). Acetate availability and its influence on sustainable bioremediation of uraniumcontaminated groundwater. Geomicrob J 28: 519-539.

Wuebbles DJ, Hayhoe K. (2002). Atmospheric methane and global change. Earth Sci Rev 57: 177-210.

Supplementary Information accompanies this paper on The ISME Journal website (http://www.nature.com/ismej) 